\title{
Aktivitas Antibakteri Kombucha Daun Sirsak (Annona muricata L.) Dengan Konsentrasi Gula Berbeda
}

\author{
(Antibacterial Activity of Soursoup Leaves Kombucha (Annona muricata L.) \\ With Different Sugar Concentration)
}

\author{
Nur Arfa Yanti*), Sri Ambardini, Ardiansyah, Wa Ode Leni Marlina, Kartika Dwi Cahyanti \\ Jurusan Biologi FMIPA Universitas Halu Oleo \\ Kampus Hijau Bumi Tridharma, Anduonohu Kendari Sulawesi Tenggara, 93231 \\ ${ }^{*}$ Penulis Korespondensi E-mail: nur.yanti@uho.ac.id
}

\begin{abstract}
Abstrak
Kombucha daun sirsak merupakan minuman hasil fermentasi simbiosis antara bakteri asam asetat Acetobacter xylinum dan khamir Saccharomyces sp. yang menggunakan bahan baku rebusan daun sirsak. Penelitian ini bertujuan untuk mengetahui aktivitas antibakteri kombucha daun sirsak dengan variasi konsentrasi gula yang berbeda. Konsentrasi gula yang digunakan dalam pembuatan kombucha daun sirsak adalah 10\%, 20\%, 30\% dan 40\% (b/v). Pengujian aktivitas antibakteri dilakukan dengan metode difusi sumuran menggunakan bakteri Escherichia coli dan Staphylococcus aureus. Kombucha daun sirsak memiliki aktivitas antibakteri dengan spektrum luas. Kombucha daun sirsak dengan konsentrasi gula 20\% memiliki aktivitas antibakteri tertinggi. Dengan demikian, kombucha daun sirsak sangat berpotensi sebagai minuman kesehatan.
\end{abstract}

Kata Kunci: aktivitas antibakteri, daun sirsak, kombucha.

\section{Abstract}

Soursop leaves Kombucha is a symbiotic fermented beverage between acetic acid bacteria, Acetobacter xylinum and yeast, Saccharomyces sp., using soursop leaf decoction. This study aims to determine the antibacterial activity of soursop leaves kombucha with different sugar concentrations. The concentration of sugar was used in making soursop leaves kombucha were $10 \%, 20 \%, 30 \%$ and $40 \%(w / v)$. Antibacterial activity testing was carried out using the well diffusion method using Escherichia coli and Staphylococcus aureus bacteria. Soursop leaves kombucha has antibacterial activity with broad spectrum activities. Soursop leaves kombucha with a sugar concentration of $20 \%$ has the highest antibacterial activity. Therefore, soursop leaves kombucha is potential as a health drink.

Keywords: antibacterial activity, soursop leaf, kombucha.

\section{PENDAHULUAN}

Kombucha merupakan minuman fermentasi dari cairan teh yang mengandung gula oleh konsorsium mikroorganisme dari kelompok bakteri asam asetat yaitu Acetobacter xylinum dan khamir yaitu Saccharomyces sp.. Kombucha dapat diproduksi dari daun-daun yang mengandung fenol tinggi sehingga dapat dimanfaatkan sebagai minuman fungsional dan sebagai pengganti teh [1]. Daun sirsak merupakan salah satu daun yang mengandung fenol tinggi [1] dan [2], selain itu pula daun sirsak mengandung senyawa steroid/terpenoid, flavonoid, alkaloid dan tanin [3], sehingga rebusan daun sirsak sangat berpotensi digunakan sebagai substrat untuk pembuatan kombucha.

Kombucha memiliki fungsi sebagai minuman yang dapat meningkatkan ketahanan tubuh, sebagai antioksidan dan antimikroba pada beberapa penyakit infeksi [4]. Umumnya, pencegahan penyakit infeksi dilakukan dengan obat-obatan sintetik termasuk antibiotik. Namun, penggunaan antibiotik yang tidak tepat sasaran seringkali mengakibatkan resistensi. Oleh karena itu dibutuhkan alternatif lain, antara lain obat herbal.

Obat-obatan herbal tidak hanya digunakan dalam fase pengobatan saja, melainkan juga digunakan dalam fase pencegahan dan penyembuhan penyakit infeksi. Salah satu obat herbal yang cukup banyak digunakan dan terbukti bermanfaat mencegah infeksi adalah teh kombucha [5] dan [6]. Teh kombucha merupakan minuman fungsional yang dapat meningkatkan jumlah sel T (limfosit T), menstimulasi sistem kekebalan tubuh dan mengandung senyawa antimikroba sehingga mampu mencegah infeksi oleh mikroba patogen [5] dan [9].

Proses pembuatan kombucha dipengaruhi oleh konsentrasi gula [7]. Konsentrasi gula yang berbeda mempengaruhi pertumbuhan mikroba kombucha dan kandungan senyawa kimia seperti asam organik [8]. Pembentukan asam-asam organik pada kombucha, menyebabkan kadar asam semakin tinggi sehingga mampu menghambat pertumbuhan mikroba patogen [9]. Oleh karena itu, penelitian ini bertujuan untuk mengetahui aktivitas antibakteri kombucha daun sirsak dan konsentrasi gula kombucha daun sirsak yang terbaik aktivitas antibakterinya.

\section{METODE PENELITIAN}

\section{Bahan Penelitian}

Bahan yang digunakan dalam penelitian ini adalah daun sirsak, gula pasir, starter kombucha, Escherichia coli ATCC 35218, Staphylococcus aureus ATCC 25923, Media 
Nutrient broth (Merck), Nutrient Agar (NA) (Merck), Agar bacteriology (Merck), NaCl 0,85\%, Standar Mc. Farland 0,5 . Phenolptalein $1 \%, \mathrm{NaOH}$, buffer $\mathrm{pH}$.

\section{Prosedur Penelitian \\ Penyiapan Daun Sirsak}

Daun sirsak diperoleh dari wilayah kota Kendari, yang diambil mulai dari daun ke-5 sampai daun ke-3 dari pangkal. Menurut Ningsih dkk. [3], daun sirsak ketiga dan kelima dari pangkal memiliki kandungan senyawa acetogenin tertinggi. Daun sirsak dicuci dengan air mengalir dan ditiriskan.

\section{Pembuatan Kombucha daun sirsak}

Tahapan pembuatan kombucha daun sirsak diawali dengan penyediaan rebusan daun sirsak. Daun sirsak disiapkan sebanyak 84 lembar daun sirsak dan direbus dalam 7,2 L air hingga air rebusan tersisa 2,4 L. Air rebusan kemudian disaring dan dibagi 4 bagian untuk ditambahkan gula sesuai perlakuan, yaitu 10\%, 20\%, 30\% dan $40 \%(\mathrm{~b} / \mathrm{v})$. Air rebusan daun sirsak yang telah ditambahkan gula, selanjutnya dipanaskan hingga mendidih selama 10 menit dan dimasukkan ke dalam bioreaktor (stoples kaca) untuk setiap perlakuan. Air rebusan kemudian didinginkan hingga suhu $\pm 25^{\circ} \mathrm{C}$, kemudian ditambahkan dengan starter kombucha yang berumur 7 hari sebanyak $8 \%(\mathrm{v} / \mathrm{v})$ pada setiap perlakuan. Bioreaktor selanjutnya ditutup dengan kain penutup dan difermentasi secara statis selama 12 hari pada suhu ruang.

\section{Analisis kadar asam total dan pH}

Analisis total asam menggunakan metode titrasi (SNI 01-3546-2004). pH kombucha daun sirsak diukur menggunakan $\mathrm{pH}$ meter ( $\mathrm{pH} 201$ digital). $\mathrm{pH}$ meter dikalibrasi dengan buffer $\mathrm{pH} 4$ dan $\mathrm{pH} 7$ sebelum digunakan untuk mengukur $\mathrm{pH}$ sampel.

\section{Uji Aktivitas Antibakteri}

Metode pengujian aktivitas antibakteri dilakukan menggunakan metode sumuran (well-difusion method) dengan 3 ulangan. Bakteri uji dipersiapkan dalam bentuk suspensi dalam larutan $\mathrm{NaCl}$ 0,85\%. Pembuatan suspensi bakteri uji dilakukan dengan cara bakteri uji yang ditumbuhkan pada media Nutrient Agar (NA) miring berumur 24 jam diambil sebanyak 1-2 jarum inokulasi (ose) dan disuspensikan ke dalam larutan $\mathrm{NaCl} 0,85 \%$ steril dan disetarakan densitasnya dengan standar Mc. Farland 0,5.

Tahapan berikutnya adalah persiapan media pertumbuhan bakteri uji, yakni media NA padat dituang ke dalam cawan petri sebagai media dasar. Pencadang steril dengan diameter $6 \mathrm{~mm}$, diletakkan di atas media dasar yang telah memadat. Suspensi bakteri uji dimasukkan sebanyak $1 \mathrm{~mL}$ ke dalam tabung reaksi media NA semi padat yang masih cair dan dihomogenkan, selanjutnya dituang ke dalam cawan petri yang telah diletakkan pencadang. Setelah media semi padat memadat, pencadang dilepas sehingga terbentuk sumuran. Kombucha daun sirsak dimasukkan ke dalam sumuran sebanyak $50 \mu \mathrm{L}$. Pada pengujian ini digunakan kontrol positif yaitu streptomycin $10 \mathrm{mg} / \mathrm{mL}$. Media uji selanjutnya disimpan di kulkas selama 30 menit untuk memberikan kesempatan kombucha sebagai agensia antibakteri berdifusi ke media. Setelah itu, media uji diinkubasi pada suhu $37^{\circ} \mathrm{C}$ selama 24 jam. Pengamatan dilakukan dengan mengukur zona hambat menggunakan jangka sorong.

\section{Analisis Aktivitas Antibakteri}

Aktivitas antibakteri dianalisis dengan cara mengukur zona hambat yang terbentuk pada media padat dengan jangka sorong. Aktivitas antibakteri diukur atau dihitung menggunakan rumus sebagai berikut [10] :

$$
\mathrm{Z}=\frac{(D 1-D s)+(D 2-D s)+(D 3-D s)}{3}
$$

Keterangan :

$$
\begin{array}{ll}
\text { Z } & =\text { Zona bening } \\
\text { D1 } & =\text { Diameter Vertikal } \\
\text { D2 } & =\text { Diameter Horizontal } \\
\text { D3 } & =\text { Diameter Diagonal } \\
\text { Ds } & =\text { Diameter Sumuran. }
\end{array}
$$

\section{HASIL DAN PEMBAHASAN}

\section{Kombucha Daun Sirsak}

Kombucha daun sirsak merupakan minuman hasil fermentasi dengan bahan dasar rebusan daun sirsak (Anonna muricata L.) dan gula yang memiliki rasa manis asam dan aroma asam yang khas. Fermentasi Kombucha daun sirsak menggunakan starter mikroba kombucha yang merupakan kultur simbiotik antara bakteri asam asetat (Acetobacter xylinum) dan khamir (Saccharomyces sp.) [5]. Hasil fermentasi kombucha daun sirsak disajikan pada Gambar 1.

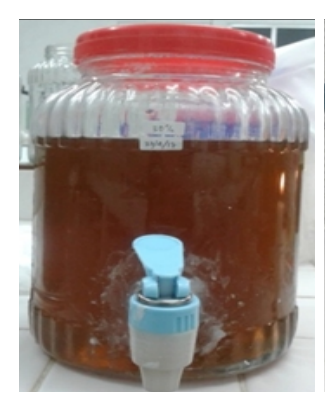

(a)

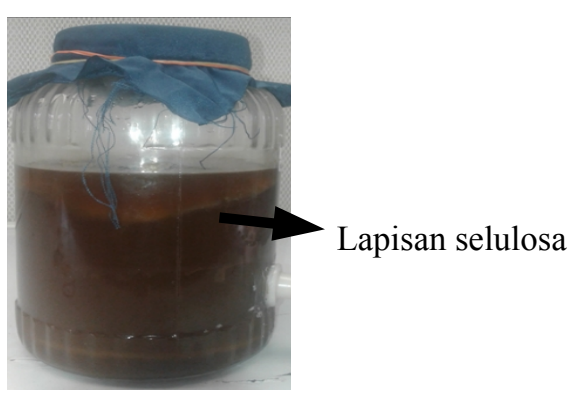

(b)
Gambar 1. Fermentasi kombucha daun sirsak pada perlakuan konsentrasi gula $20 \%$. (a) sebelum fermentasi, (b) setelah fermentasi

Keberhasilan proses fermentasi rebusan daun sirsak menjadi kombucha ditandai dengan terbentuknya lapisan putih yang mengapung di permukaan media yang disebut lapisan selulosa (Gambar 1). Lapisan selulosa dapat terbentuk karena selama fermentasi, oksigen di permukaan media akan menstimulasi peningkatan massa sel bakteri Acetobacter xylinum dan enzim selulosa sintase yang akan mensintesis selulosa dari glukosa, akibatnya produksi selulosa meningkat dan membentuk lapisan-lapisan [9]. Adanya gas karbondioksida akan menyebabkan lapisan selulosa mengapung di permukaan dan apabila selulosa telah terbentuk di permukaan kombucha, maka oksigen yang tersedia tidak sebanyak sebelumnya karena permukaan kombucha tertutup lapisan selulosa [9] dan [11]. Mikroba yang berperan dalam proses fermentasi Kombucha antara lain bakteri asam asetat yaitu Acetobacter xylinum 
Tabel 1. Kadar asam total dan $\mathrm{pH}$ kombucha daun sirsak

\begin{tabular}{ccc}
\hline Perlakuan & Kadar asam Total $(\%)$ & $\mathrm{pH}$ \\
\hline Rebusan daun sirsak & 0,002 & 5,00 \\
Kombucha + gula 10\% & 0,083 & 3,51 \\
Kombucha + gula 20\% & 0,097 & 3,48 \\
Kombucha + gula 30\% & 0,104 & 3,45 \\
Kombucha + gula 40\% & 0,113 & 3,37 \\
\hline
\end{tabular}

dan beberapa jenis khamir seperti Saccharomyces sp. Candida sp. dan Pichia sp. [5], [9] dan [11]. Bakteri asam asetat merupakan bakteri aerob yang cenderung ada di bagian permukaan karena membutuhkan oksigen, sedangkan khamir berada di bagian bawah untuk kemudian beralih melakukan fermentasi anaerob yang memproduksi alkohol yang akan digunakan oleh bakteri asam asetat [9] dan [11].

Pada proses fermentasi yang dilakukan oleh konsorsium mikroba kombucha (A,xylinum dan Saccharomyces sp.), diproduksi pula asam organik selain lapisan selulosa. Total asam organik yang terbentuk dan $\mathrm{pH}$ kombucha daun sirsak ditampilkan pada Tabel 1.

Pembentukan asam organik pada kombucha daun sirsak terjadi setelah proses fermentasi. Hal ini ditunjukkan dengan kadar asam total pada rebusan daun sirsak yang belum difermentasi sangat rendah yaitu $0,002 \%$, sedangkan rebusan daun sirsak yang telah difermentasi menjadi kombucha lebih tinggi, berkisar 0,083-0,113\% (Tabel 1). Hasil ini mengindikasikan bahwa keberadaan asam organik pada kombucha daun sirsak merupakan aktivitas dari mikroba yang berperan dalam proses fermentasi kombucha (starter), yakni bakteri asam asetat (Acetobacter xylinum) dan khamir (Saccharomyces sp.). Selama fermentasi berlangsung, khamir akan merombak sukrosa yang terdapat pada medium fermentasi menjadi glukosa dan fruktosa, kemudian glukosa dikonversi menjadi asam asetat dan selulosa oleh bakteri asam asetat [12]. Asam organik lainnya selain asam asetat yang dihasilkan dalam proses fermentasi kombucha adalah asam glukonat, asam glukoronat dan asam laktat [9]. Glukosa, fruktosa dan asam-asam organik yang terbentuk dalam kombucha [9], menyebabkan kombucha mempunyai cita rasa asam manis.

Tabel 1 juga menunjukkan bahwa semakin tinggi konsentrasi gula (sukrosa) pada kombucha daun sirsak, maka semakin tinggi pula kadar asam totalnya. Hal ini disebabkan karena gula sebagai substrat untuk memproduksi asam organik, tersedia bagi starter kombucha sehingga jumlah asam organik yang dihasilkan lebih banyak. Marwati dkk. [7] menyatakan bahwa sukrosa merupakan substrat yang dikonversi menjadi glukosa dan selanjutnya digunakan untuk pertumbuhan sel dan pembentukan asam-asam organik seperti asam asetat.

Berdasarkan Tabel 1 diketahui pula bahwa semakin tinggi kadar asam total pada kombucha daun sirsak, maka nilai pH kombucha akan semakin rendah. Kumar \& Joshi [9] menyatakan bahwa akumulasi zat asam dan peningkatan jumlah proton $\mathrm{H}^{+}$sebagai hasil dari metabolisme mikroba selama proses fermentasi membuat $\mathrm{pH}$ semakin menurun atau asam. $\mathrm{pH}$ rebusan daun sirsak sebelum difermentasi adalah 5 dan menurun berkisar 3 setelah difermentasi menjadi kombucha (Tabel 1). Hasil ini sesuai dengan laporan BC Centre for Disease Control-Enviromental Health Services [13] tentang keamanan pangan kombucha, yakni $\mathrm{pH}$ awal teh sebelum difermentasi dimulai dari $\mathrm{pH}$, selanjutnya nilai $\mathrm{pH}$ setelah fermentasi harus berkisar antara 2,5 - 4,2. Nilai $\mathrm{pH}$ kombucha yang baik untuk dikonsumsi adalah 3,2 [3]. Berdasarkan standar $\mathrm{pH}$ kombucha, maka kombucha daun sirsak sangat potensial untuk dikonsumsi.

\section{Aktivitas Antibakteri Kombucha Daun Sirsak}

Penentuan aktivitas antibakteri kombucha daun sirsak dilakukan secara in-vitro, berdasarkan kemampuannya menghambat pertumbuhan bakteri uji yaitu Escherichia coli ATCC 35218 yang mewakili bakteri Gram negatif dan Staphylococcus aureus ATCC 25923 yang mewakili bakteri Gram positif. Hasil pengujian aktivitas antibakteri kombucha daun sirsak terhadap E. coli dan $S$. aureus ditampilkan pada Gambar 2.

Berdasarkan hasil penelitian yang ditampilkan pada Gambar 2, diketahui bahwa rebusan daun sirsak memiliki aktivitas antibakteri jika difermentasi menjadi kombucha yang diindikasikan dengan terbentuknya zona jernih sedangkan rebusan daun sirsak tanpa fermentasi tidak memiliki aktivitas antibakteri, Aktivitas antibakteri dari kombucha daun sirsak disebabkan karena pada kombucha daun sirsak mengandung senyawa-senyawa yang mampu menghambat pertumbuhan bakteri seperti asam-asam organik, yang ditunjukkan dengan kadar asam total seperti pada Tabel 1. Asam organik yang paling banyak terbentuk pada kombucha adalah asam asetat [5] dan [9]. Menurut Sreeramulu et al. [5], terbentuknya asam asetat pada kombucha mampu menghambat pertumbuhan bakteri Gram positif maupun bakteri Gram negatif. Kumar \& Joshi [9] juga menyatakan bahwa asam asetat pada kombucha merupakan senyawa yang paling bertanggung jawab sebagai agensia antibakteri. Naidu [14] menyatakan bahwa asam asetat yang terbentuk di dalam kombucha akan terurai melepaskan proton-proton bebas sehingga $\mathrm{pH}$ media turun.

Asam asetat yang tidak terdisosiasi dapat merusak struktur bilayer lipid bakteri dan memasukkan proton ke dalam sitoplasma. Jumlah proton intraseluler yang banyak, membuat sitoplasma dalam kondisi asam, sehingga menyebabkan denaturasi protein dan kehilangan energi [14]. Oleh karena itu, kandungan asam asetat yang tinggi dapat menghambat pertumbuhan bakteri [14].Selain itu pula, asam organik yang terbentuk pada kombucha daun sirsak menurunkan pH substrat dari 5 menjadi 3,37-3,51 (Tabel 1) dan $\mathrm{pH}$ substrat yang rendah mempengaruhi pertumbuhan bakteri. Kumar \& Joshi [9] menyatakan bahwa $\mathrm{pH}$ media yang rendah, dapat menyebabkan kerusakan sel yang parah karena sitoplasma bakteri menjadi asam. 


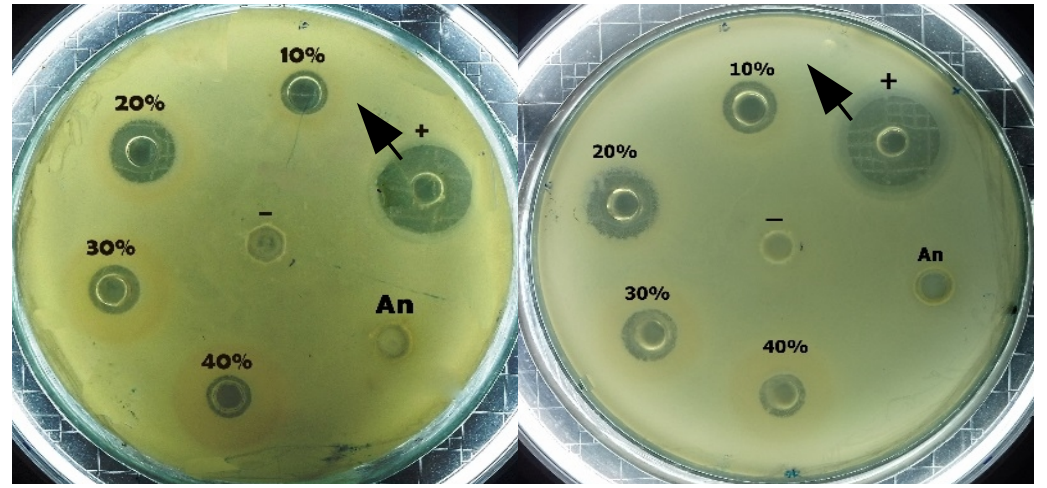

(a)

(b)

Gambar 2. Hasil pengujian aktivitas antibakteri kombucha daun sirsak. (a) Escherichia coli (b) Staphylococcus aureus.

Keterangan : + : kontrol positif (antibiotik streptomisin), - : kontrol negatif (akuades steril), 10-40\% : perlakuan konsentrasi gula kombucha daun sirsak, An : rebusan daun sirsak, Tanda panah : Zona jernih/hambat

Tabel 2. Aktivitas antibakteri kombucha daun sirsak setelah difermentasi 12 hari

\begin{tabular}{lccc}
\hline \multirow{2}{*}{ Perlakuan } & \multicolumn{2}{c}{ Diameter zona hambat (mm) } & \multirow{2}{*}{ Interpretasi $^{[17]}$} \\
\cline { 2 - 3 } & E.coli & S.aureus & \\
\hline Kombucha+gula $10 \%$ & 14,94 & 15,86 & Intermediet \\
Kombucha+gula $20 \%$ & 16,28 & 17,08 & Intermediet \\
Kombucha+gula 30\% & 15,72 & 16,36 & Intermediet \\
Kombucha+gula 40\% & 15,26 & 16,07 & Intermediet \\
Kontrol + (streptomisin) & 18,47 & 19,58 & Intermediet \\
\hline
\end{tabular}

Gambar 2 menunjukkan bahwa kombucha daun sirsak dengan perlakuan konsentrasi gula $10-40 \%$ membentuk zona jernih disekeliling sumurannya pada bakteri E.coli dan $S$. aureus dan hal ini mengindikasikan bahwa kombucha daun sirsak memiliki aktivitas antibakteri karena mampu menghambat pertumbuhan kedua bakteri uji tersebut. Hasil ini diperkuat dengan terbentuknya zona jernih pada streptomisin (kontrol +), yang merupakan antibiotik komersil yang bersifat bakterisidal terhadap bakteri Gram positif maupun Gram negatif [15]. Kemampuan kombucha daun sirsak menghambat pertumbuhan bakteri Gram negatif E.coli dan bakteri Gram postif S.aureus, mengindikasikan bahwa kombucha daun sirsak memiliki aktivitas antibakteri dengan spektrum luas. Acar [16] menyatakan bahwa antibiotik yang mampu menghambat pertumbuhan bakteri Gram positif maupun Gram negatif merupakan antibiotik berspektrum luas. Hasil penelitian ini sesuai dengan penelitian yang dilaporkan oleh Battikh et al. [17] bahwa kombucha teh hitam dan hijau mempunyai aktivitas antibakteri dengan spektrum luas, karena mampu menghambat bakteri Gram positif maupun Gram negatif.

Aktivitas penghambatan kombucha daun sirsak terhadap bakteri ditentukan berdasarkan diameter zona jernih (zona hambat). Berdasarkan luas zona hambat yang dihasilkan oleh kombucha daun sirsak, maka dapat ditentukan interpretasi aktivitas antibakteri kombucha tersebut terhadap bakteri yang diujikan. Aktivitas antibakteri kombucha daun sirsak terhadap bakteri E.coli dan S. aureus ditampilkan pada Tabel 2.

Tabel 2 menunjukkan bahwa diameter zona hambat kombucha daun sirsak terhadap E.coli berkisar 14,94-16,28 mm sedangkan S.aureus berkisar 15,86-17,08 mm dengan kategori intermediet/sedang. Harmita \& Radji [18] menyatakan bahwa interpretasi aktivitas antibakteri suatu agensia berdasarkan besaran zona jernih terbagi menjadi tiga kategori yaitu lemah jika diameter zona jernih yang dihasilkan $\leq 11 \mathrm{~mm}$, intermediet/sedang jika diameter zona hambat yang dihasilkan berkisar antara 12-21 mm, dan tergolong kuat jika diameter zona jernih yang dihasilkan $\geq$ $22 \mathrm{~mm}$ [18]. Luasnya zona jernih atau zona hambat yang terbentuk selama fermentasi merupakan petunjuk kepekaan mikroorganisme terhadap senyawa antimikroba yang dihasilkan [19]. Agensia antimikroba yang memiliki zona jernih besar, menunjukkan daya antimikroba tersebut sangat baik [15] dan [18].

Kombucha daun sirsak yang ditambahkan gula sebanyak $20 \%$ memiliki aktivitas antibakteri yang tertinggi, sedangkan kombucha dengan konsentrasi gula $10 \%$ memiliki aktivitas antibakteri terendah (Tabel 2). Tabel 2 juga menunjukkan bahwa konsentrasi gula pada kombucha daun sirsak yang semakin tinggi (lebih dari 20\%), menurunkan daya hambatnya terhadap bakteri uji, yang mengindikasikan bahwa aktivitas antibakterinya menurun. Hasil penelitian yang sama diperoleh oleh Ziska dkk. [20], yang melaporkan bahwa konsentrasi sukrosa yang semakin tinggi pada minuman probiotik air kelapa menurunkan aktivitas antibakterinya. Hasil ini menunjukkan bahwa konsentrasi gula 20\% merupakan konsentrasi optimum bagi pertumbuhan mikroba, dan konsentrasi gula yang terlalu tinggi dapat menurunkan jumlah sel mikroba dan aktivitasnya. Hal ini didukung dengan pernyataan Sintasari dkk. [21], bahwa kadar gula yang terlalu tinggi dapat menurunkan jumlah mikroba yang berakibat pada menurunnya aktivitas mikroba tersebut dalam proses fermentasi. Mikroba yang berperan dalam fermentasi memiliki batasan optimal untuk memanfaatkan gula sebagai 
sumber energi sehingga tidak semua gula yang terkandung dalam produk dapat dikonversi menjadi produk metabolit sekunder [21]. Aktivitas antibakteri dari minuman fermentasi dipengaruhi oleh jumlah sel dan aktivitas mikroba dalam menekan pertumbuhan bakteri patogen [22] dan [23].

Tabel 2 juga menunjukkan bahwa kombucha daun sirsak memiliki diameter zona hambat yang lebih tinggi pada S.aureus yang merupakan bakteri Gram positif dibandingkan bakteri Gram negatif, yakni E.coli. Hasil ini mengindikasikan bahwa kombucha daun sirsak memiliki aktivitas antibakteri yang lebih tinggi terhadap bakteri Gram positif dibandingkan bakteri Gram negatif. Hal ini disebabkan karena metabolit sekunder yang dihasilkan oleh mikroba kombucha mampu merusak komponen peptidoglikan pada dinding sel bakteri, dan komponen peptidoglikan bakteri Gram positif lebih tinggi dibandingkan bakteri Gram negatif sehingga dinding sel bakteri Gram positif lebih mudah dirusak oleh kombucha sebagai agensia antimikroba [5]. Shan et al. [24] menyatakan bahwa komponen peptidoglikan pada dinding sel bakteri lebih mudah dirusak oleh metabolit sekunder dari tanaman maupun mikroba. Hasil penelitian ini sesuai dengan penelitian yang dilakukan oleh Shan et al. [24] dan Borkani et al. [25] yang melaporkan bahwa kombucha memiliki aktivitas antibakteri yang lebih tinggi terhadap bakteri Gram positif S.aureus. Menurut Kohanski, et al. [26], sensitivitas bakteri terhadap antibiotik tergantung kapada kemampuan antibiotik tersebut untuk menembus dinding sel bakteri. Antibiotik lebih banyak yang efektif bekerja terhadap bakteri Gram positif karena permeabilitas dinding selnya lebih tinggi dibandingkan bakteri Gram negatif. Selain itu pula, bakteri Gram negatif Escherichia coli, memiliki kapsul yang tidak mudah di rusak dengan antibiotik [19].

\section{KESIMPULAN}

Berdasarkan hasil penelitian dapat disimpulkan bahwa kombucha daun sirsak memiliki aktivitas antibakteri dan baik digunakan sebagai minuman kesehatan. Kombucha daun sirsak dengan konsentrasi gula 20\% memiliki aktivitas antibakteri tertinggi, dengan daya hambat terhadap Escherichia coli sebesar 16,28 $\mathrm{mm}$ dan Staphylococcus aureus sebesar $17,08 \mathrm{~mm}$.

\section{DAFTAR PUSTAKA}

[1] D. Wistiana dan E. Zubaidah, 2015, Karakteristik Kimiawi dan Mikrobiologis Kombucha dari Berbagai Daun Tinggi Fenol Selama Fermentasi, Jurnal Pangan dan Agroindustri, vol. 3(04), pp.1446-1457, 2015.

[2] P.N. Suhardini dan E. Zubaidah, Studi Aktivitas Antioksidan Kombucha dari Berbagai Jenis Daun Selama Fermentasi, Jurnal Pangan dan Agroindustri, vol. 4(1) pp. 221-229, 2016.

[3] D.R. Ningsih, Zusfahair dan D. Kartika, Identifikasi Senyawa Metabolit Sekunder serta Uji Aktivitas Ekstrak Daun Sirsak sebagai Antibakteri. Molekul Vol. 11 (1), pp. 101-111. 2016.

[4] M. Muizuddin dan E. Zubaidah, Studi Aktivitas Antibakteri Kefir Teh Daun Sirsak (Annona muricata
Linn.) Dari Berbagai Merk Teh Daun Sirsak Dipasaran, Jurnal Pangan dan Agroindustri, vol.3(4), pp.1662-1672, 2015.

[5] G. Sreeramulu, Y. Zhu and W. Knol, Kombucha Fermentation and its Antimicrobial Activity, Journal Agricultural Food Chemistry, Vol. 48(6), pp.25892594, 2000.

[6] R. Jayabalan, P. Subathradevi, S. Marimuthu, M. Sathishkumar and K. Swaminathan, Changes in Freeradical Scavenging Ability of Kombucha tea during fermentation, Food Chemistry, Vol. 109 (1) : pp. 227234, 2008.

[7] H. Marwati, Syahrumsyah dan R. Handria, Pengaruh Konsentrasi Gula dan Starter Terhadap Mutu Teh Kombucha, Jurnal Teknologi Pertanian, Vol. 8(2), pp.49-53, 2013.

[8] R. Simanjuntak dan S. Natalina, Pengaruh Konsentrasi Gula dan Lama Fermentasi terhadap Mutu Teh Kombucha, Jurnal Ilmiah Pendidikan Tinggi, Vol. 4(2), pp. 81-91, 2011.

[9] V. Kumar and V.K. Joshi. Kombucha :Technology, Microbiology, Production, Composition and Therapeutic Value, Intl. J. Food. Ferment. Technol. Vol. 6 (1), pp.13-24, 2016.

[10] Y. Warbung, N.S. Vonny, N. Wowor, P. Jimmy.. Daya Hambat Ekstrak Spons Laut Callyspongia sp terhadap Pertubuhan Bakteri Staphylococcus aureus. Repository, Fakultas Kedokteran Gigi, Universitas Sam Ratulangi, pp. 1-3, 2013.

[11] S. Chakravorty, S. Bhattacharya, D. Bhattacharya, S. Sarkar, and R. Gachhui. Kombucha : A Promising Functional Beverage Prepared from Tea, Nonalcoholic Beverages. https://doi.org/10.1016/B978-012-815270-6.00010-4, pp. 285-327, 2019.

[12] D. Hidayat, Mikrobiologi Industri. C.V Andi offset. Yogyakarta, 2006.

[13] BCCDC (Brithis Columbia Centre for Disease Control's Enviromental Health Services), Food Safety Assessment of Kombucha Tea Recipe and Food Safety Plan. Columbia, 2015.

[14] A.S. Naidu. Natural Food Antimicrobial Systems. CRC Press. New York, 2000.

[15] D.G. Allison and P.A. Lambert. Chapter 32 - Modes of Action of Antibacterial Agents in Molecular Medical Microbiology 2nd edition : 583-598. Academic Press, 2015.

[16] J. Acar, Broad- and narrow-spectrum antibiotics: an unhelpful categorization, Clin. Microbiol. Infect. Vol. 3 (4), pp. 395-396, 1997.

[17] H. Battikh, K. Chaeib, A. Bakhrouf and E. Ammar, Antibacterial and Antifungal Activities of Black and Green Kombucha Teas, Journal of Food Biochemistry Vol. 37(2) pp. 231-236, 2013.

[18] Harmita dan M. Radji, Kepekaan Antibiotik dalam Buku Ajar Analisis Hayati Ed. 3, EGC, Jakarta, pp. 15, 2008.

[19] E. Jawetz, J. Melnick, and E. Adelberg, Mikrobiologi Kedokteran, Ed ke-20. Nugroho, E., Maulany, F. R., penerjemah; Jakarta: Buku Kedokteran. Terjemahan dari: Review of Medical Microbiology, 1996. 
[20] R. Sizka, A.Taufik dan D. Supriadi. Uji Aktivitas Antimikroba dan Antioksidan dari Minuman Probiotik Hasil Fermentasi Air Kelapa (Cocos nucifera), Jurnal Farmasi Galenika Vol 4(1), pp. 14-19, 2017.

[21] R.A. Sintasari, J. Kusnadi, dan D.W. Ningtyas. Pengaruh Penambahan Konsentrasi Susu Skim dan Sukrosa terhadap Karakteristik Minuman Probiotik Sari Beras Merah. Jurnal Pangan dan Agroindustri Vol. 2 (3), pp. 65-75, 2014.

[22] R. Jayabalan, R.V. Malbasa, E.S. Loncar, J.S. Vitas. And M. Sathishkumar. A Review on Kombucha TeaMicrobiology, Composition, Fermentation, Beneficial Effects, Toxicity, and Tea Fungus, Comprehensive Reviews in Food Science and Food Safety, Vol. 13, pp. 538-550, 2014.

[23] R.J.S. Junior, R.A. Batista, S.A. Rodrigues, L.X. Filho and A.S. Lima, Antimicrobial Activity of Broth Fermented with Kombucha Colonies, Journal of Microbial \& Biochemical Technology, Vol. 1(1), pp. 027-07, 2009.

[24] B. Shan, Y.Cai, J.D. Brooks and H. Cork, The In Vitro Antibacterial Activity of Dietary Spice and Medicinal Herb Extracts. International Journal of Food Microbiology,117(1), pp.112-119, 2007.

[25] R.A. Borkani, D. Monir and R. Zahra, Study of the Anti-Bacterial Effects of Green and Black Kombucha Teas and Their Synergetic Effect against Some Important Gram Positive Pathogens Transmitted by Foodstuff, International Journal of Advanced Biotechnology and Research, Vol. 7(3), pp.17411747, 2016.

[26] M.A. Kohanski, D.J. Dwyer and J.J. Collins, How antibiotics kill bacteria: from targets to networks, Nat Rev Microbiol. Vol. 8 (6): 423-435, 2010. 